\title{
BAHAN AJAR MENULIS OPINI DAN ESAI DENGAN PEMBELAJARAN BERBASIS PROYEK
}

\author{
Sakaria dan Asis Nojeng \\ Fakultas Keguruan dan Ilmu Pendidikan, Universitas Muhammadiy ah Makassar \\ Jalan Sultan Alauddin, Rappocini, Makassar \\ Surel: sakariaunm@y ahoo.co.id
}

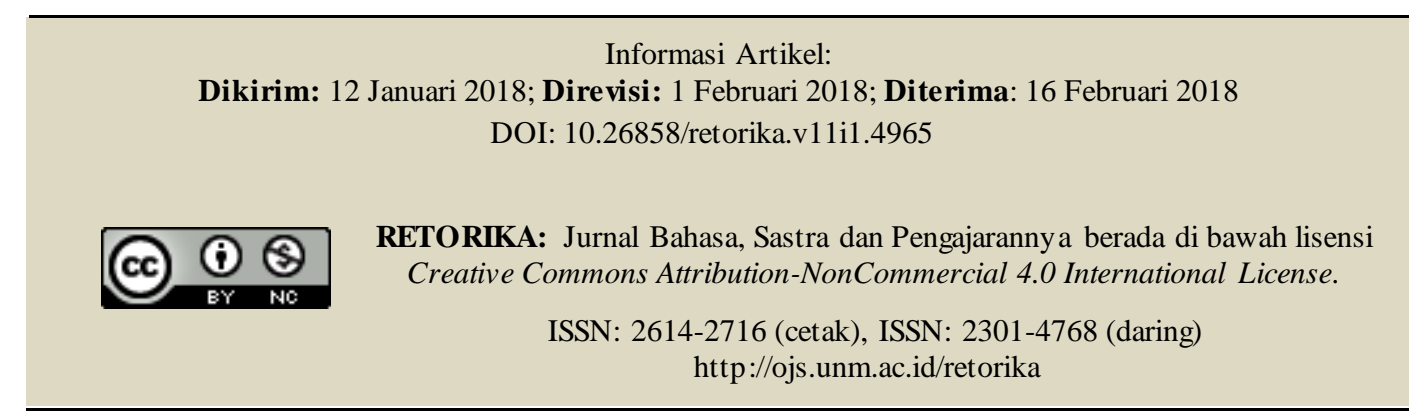

\begin{abstract}
The Instructional Writing Material of Opinion and Essays with Problem Based Learning. This study aims to describe the feasibility and effectiveness of writing articles of opinion and project-based essay articles. Teaching materials were developed using the ADDIE model at the Muhammadiyah University of Makassar. The results showed that the developed teaching materials have been feasible and effectively used in the study of opinion writing and essay. The teaching materials are worthy of use because they meet the aspects of eligibility that are content feasibility, presentation feasibility, and language feasibility. Effective teaching materials are used because there are significant differences in student learning outcomes before using and after using teaching materials.
\end{abstract}

Abstrak: Bahan Ajar Menulis Opini dan Esai dengan Pembelajaran Berbasis Masalah. Penelitian ini bertujuan mendeskripsikan kelayakan dan keefektifan bahan ajar menulis opini dan artikel esai dengan pembelajaran berbasis proyek. Bahan Ajar dikembangkan dengan menggunakan model ADDIE di Universitas Muhammadiyah Makassar. Hasil penelitian menunjukkan bahwa bahan ajar yang dikembangkan telah layak dan efektif digunakan dalam pembelajaran menulis opini dan esai. Bahan ajar layak digunakan karena telah memenuhi aspek kelayakan, yakni kelayakan isi, kelayakan penyajian, dan kelayakan bahasa. Bahan ajar efektif digunakan karena terdapat perbedaan yang siginifikan hasil belajar mahasiswa sebelum meng gunakan dan setelah menggunakan bahan ajar.

Kata kunci: keterampilan menulis, opini, esai, pembelajaran berbasis proyek 
Keterampilan menulis merupakan salah satu keterampilan akademik yang diperlukan mahasiswa, bukan hanya untuk menentukan kesuksesan perkuliahan, tetapi juga untuk menunjang kesuksesan di dunia profesional. Oleh karena itu, keterampilan menulis menjadi salah satu aspek terpenting dari berbagai keterampilan belajar yang hendak diperdalam mahasiswa ketika memasuki pembelajaran di perguruan tinggi (Piršl, Piršl, dan Dalibor, 2011). Lebih lanjut, temuan Piršl, Piršl, dan Dalibor menunjukkan bahwa mahasiswa menginginkan mempelajari keterampilan menulis yang lebih kompleks dibandingkan dengan pembelajaran menulis yang telah mereka peroleh di sekolah menengah. Mahasiswa mempersepsikan bahwa perubahan tuntutan kompetensi menulis perlu diiringi dengan pemerolehan keterampilan yang lebih kompleks. Hasil penelitian tersebut hendaknya menjadi landasan dalam penyelenggaraan perkuliahan di perguruan tinggi agar dapat mewadahi pengembangan kompetensi menulis mahasiswa dalam rangka memenuhi kebutuhan belajar dan keterampilan profesional setelah menamatkan pendidikan.

Kegiatan menulis merupakan kegiatan yang menggunakan proses berpikir. Proses berpikir tersebut dilakukan dalam dua hal, yakni apa dan bagaimana cara menulis. Apa yang ditulis berkaitan dengan gagasan atau materi yang akan ditulis, sedangkan bagaimana cara menulis berkaitan dengan pengembangan gagasan. Menulis merupakan salah satu tantangan kognitif utama karena keterampilan ini memerlukan ujian kemampuan mengingat, berbahasa, dan berpikir sekaligus (Kellog \& Raulerson III, 2007). Proses menggali materi tulisan dilakukan melalui kegiatan pemilihan topik, pengumpulan bahan, perencanaan penataan tulisan, penetapan tujuan menulis, dan pengembangan gagasan. Menulis merupakan hasil akhir dan pekerjaan merangkai kata, kalimat, dan alinea untuk menjabarkan atau mengulas topik dan tema tertentu (Finoza, 2009: 192).

Menulis merupakan suatu keterampilan berbahasa yang digunakan untuk berkomunikasi secara tidak langsung. Menulis adalah kegiatan yang aktif dan produktif serta memerlukan cara berpikir yang teratur yang diungkapkan dalam bahasa tulis. Dalam kegiatan menulis, seorang penulis harus terampil memanfaatkan grafologi, struktur bahasa, dan kosakata. Sehubungan dengan hal itu, keterampilan menulis digunakan untuk mengungkapkan ide, pikiran, gagasan, pengetahuan, ilmu dan pengalaman sebagai suatu kemampuan yang produktif.

Sejumlah studi yang dilakukan untuk mengukur kemampuan menulis mahasiswa menunjukkan hasil yang kurang menggembirakan. Persadha (2016) menemukan bahwa kompetensi menulis mahasiswa hanya berkategori cukup pada aspek isi, organisasi, kosakata dan istilah, penggunaan bahasa, dan ejaan. Khusus dalam keterampilan menulis esai, penelitian Rasyidah dan Antoni (2014) menungungkap bahwa kemampuan mahasiswa hanya berada pada kategori cukup. Hasil-hasil penelitian yang telah dipaparkan menunjukkan bahwa aspek-aspek keterampilan dasar yang dibutuhkan oleh mahasiswa untuk menghasilkan tulisan yang berkualitas sangat diperlukan pengembangannya. Faktor-faktor yang berpengaruh terhadap capaian temuan tersebut, mencakup motivasi, jenis tulisan, pengetahuan yang telah dimiliki sebelumnya serta tingkat kesulitan jenis tulisan yang hendak dihasilkan.

Menulis opini dan esai merupakan dua wujud keterampilan yang dikembangkan bagi mahasiswa. Kegiatan menulis opini dan esai, selain mementingkan unsur keterampilan menulis juga memperhatikan aspek argumen, penalaran, dan data faktual agar dapat menghasilkan tulisan yang baik. Menulis opini dan esai memerlukan strategi dalam menemukan dan mengembangkan ide. Untuk mengembangkan keterampilan menulis esai mahasiswa, Perutz (2010) memperkenalkan enam langkah, yakni (1) menganalisis kata kunci dan pertanyaan untuk dikembangkan menjadi tulisan, (2) perencanaan tulisan, (3) menggunakan perencanaan untuk melakukan riset tulisan, (4) merevisi perencanaan, (5) menyusun draf, dan (6) mengedit draf. Pengembangan keterampilan menulis opini mahasiswa dapat dilakukan melalui strategi: (1) berani dalam memilih dan mengembangkan topik yang aktual, (2) menuliskan ide dan gagasan dengan singkat, (3) menulis dengan cepat ide-ide brilian yang ditemukan, (4) mengembangkan gaya bertutur dalam menulis, dan (5) melakukan persiapan untuk mengembangkan tulisan dan menerima respon setelah terpublikasi (Gasman, 2014). Pemaduan antara penguasaan aspek isi tulisan dan strategi menulis akan membantu mahasiswa mengembangkan keterampilan menulis opini dan esai.

Opini merupakan karya ilmiah populer yang mengacu pada referensi pemikiran yang berlaku. Artinya, opini berawal dari fakta-fakta yang ada lalu dicetuskan alam bentuk gagasan 
atau pendapat. Adapun, esai adalah tulisan berbentuk prosa yang membahas tentang sebuah masalah secara sepintas dari sudut pandang pribadi penulisnya, kekuatan esai tertumpu pada daya analisis. Keterampilan menulis opini dan esai penting untuk dikuasai mahasiswa sebab melalui keterampilan menulis opini dan esai, mahasiswa diharapkan mampu menyampaikan fakta, pengetahuan, ide, dan gagasan kepada orang lain dengan argumen, penalaran, dan data faktual yang tepat.

Menulis opini dan esai merupakan salah satu mata kuliah yang diajarkan pada Program Studi Pendidikan Bahasa dan Sastra Indonesia, Universitas Muhammadiyah Makassar. Melalui studi pendahuluan, penulis menemukan bahwa perkuliahan menulis opini dan esai belum berlangsung secara maksimal. Temuan penulis menunjukkan bahwa ketersediaan bahan ajar menjadi salah satu faktor yang berkontribusi terhadap belum maksimalnya perkuliahan. Berdasarkan hasil studi pendahuluan, teridentifikasi dua aspek bahan ajar yang memerlukan perbaikan, yakni subtansi isi bahan ajar dan kegiatan mahasiswa yang dikembangkan untuk menumbuhkan keterampilan menulisnya. Dari aspek subtansi, bahan ajar yang tersedia belum dapat membantu mahasiswa menguasai tata cara menyusun argumen, penalaran, dan data faktual dalam menyampaikan fakta, pengetahuan, ide maupun gagasan pada tulisan opini dan esai. Dari aspek kegiatan mahasiswa, bahan ajar yang digunakan dalam pembelajaran menulis opini dan esai saat ini belum berfokus pada aspek keterampilan menulis mahasiswa. Hal tersebut, berdampak pada tulisan opini dan esai yang dihasilkan mahasiswa kurang berkualitas dan tidak menarik. Dampak lanjutan dari permasalahan bahan ajar ini, kemampuan menulis opini dan esai yang diindikasikan oleh hasil belajar keterampilan menulis mahasiswa kurang maksimal.

Bertolak dari realitas tersebut, peneliti memandang perlu adanya pengembangan bahan ajar menulis artikel opini dan esai. Bahan ajar yang dikembangkan melalui penelitian ini adalah bahan ajar dengan pembelajaran berbasis proyek. Selain memberikan kebaruan dalam wujudnya, bahan ajar menulis opini dan esai dengan pembelajaran berbasis proyek juga diyakini dapat menumbuhkan keterampilan menulis mahasiswa. Bahan ajar berbasis proyek salah satu bentuk bahan ajar yang menuntun mahasiswa untuk menggali konten (substansi materi) dengan menggu- nakan berbagai cara yang bermakna bagi dirinya dan melakukan eksperimen secara kolaboratif (Sakaria, Anshari, \& Nurhikah, 2016).

Pembelajaran berbasis proyek merupakan model pembelajaran yang menghubungkan antara belajar dan lingkungan (Sanjaya, 2009:91). Lingkungan memberi masukan kepada mahasiswa berupa bantuan masalah, sedangkan sistem saraf otak berfungsi menafsirkan bantuan itu efektif sehingga masalah yang dihadapi dapat diselidiki, dinilai, dianalisis serta dicari pemecahannya dengan baik (Trianto, 2012:93). Pengalaman yang diperoleh dari lingkungan akan menjadi bahan dan materi yang mendukung tujuan belajarnya. Keunggulan bahan ajar berbasis proyek, yakni: (1) meningkatkan motivasi belajar mahasiswa untuk belajar, mendorong kemampuan mahasiswa untuk melakukan pekerjaan penting, (2) meningkatkan kemampuan memecahkan masalah, (3) membuat mahasiswa menjadi lebih aktif dan berhasil memecahkan masalah-masalah yang kompleks, (4) mendorong mahasiswa untuk mengembangkan dan mempraktikkan keterampilan komunikasi, dan (5) meningkatkan keterampilan mahasiswa dalam mengelola sumber belajar (Dimyati dan Mujiono, 2013:42).

Hasil-hasil penelitian yang dikembangkan dengan pembelajaran berbasis proyek menunjukkan keefektifan. Wajdi (2017) yang mengembangkan pembelajaran berbasis proyek dalam pembelajaran drama menunjukkan hasil yang efektif: pembelajaran dapat diimplementasikan dengan muda dan nilai pembelajaran menunjukkan hasil yang memuaskan. Suhartatik \& Adi (2014) menemukan bahwa pembelajaran berbasis proyek dapat meningkatkan keterampilan berbahasa Inggris dan membantu menyelesaikan masalah-masalah dalam belajar. Dalam hal motivasi belajar, Tamim dan Grant (2013) menemukan bahwa penggunaan pembelajaran berbasis proyek berhasis meningkatkan motivasi dan melibatkan secara aktif peserta didik dalam belajar.

Berbeda dengan penelitian yang telah dipaparkan, penelitian yang dikembangkan ini berfokus pada pengembangan bahan ajar menulis teks opini dan esai dengan pendekatan berbasis proyek.

\section{METODE}

Penelitian ini merupakan merupakan penelitian pengembangan. Penelitian ini dicirikan 
melalui proses untuk mengembangkan suatu produk, menguji kelayakan dan keefektifan produk. Fokus penelitian adalah pengembangan bahan ajar menulis opini dan esai berbasis proyek yang layak dan efektif. Produk dikembangkan dengan menggunakan model $A D D I E$ dan diuji kelayakan serta efektifitasnya. Produk yang dihasilkan berupa bahan ajar menulis teks opini dan esai berbasis proyek. Bahan ajar dikembangkan menggunakan model $A D D I E$ yang meliputi tahap analisis, desain, pengembangan, implementasi dan evaluasi (Mulyatiningsih, 2012). Uji lapangan dilakukan dengan melibatkan 35 orang mahasiswa Program Studi Pendidikan Bahasa dan Sastra Indonesia, Universitas Muhammadiyah Makassar. Uji coba lapangan bahan ajar dilakukan dengan menggunakan desain eskperimen one group pretest-posttest design. Penentuan subjek uji coba dilakukan dengan teknik cluster sampling.

Instrumen yang digunakan adalah angket validasi ahli dan tes menulis opini dan esai. Data penelitian terdiri atas data kualitatif dan data kuantitatif. Data kelayakan bahan ajar diperoleh dari hasil validasi ahli. Sebanyak dua orang ahli pembelajaran bahasa dan sastra Indonesia dilibatkan sebagai validator. Setiap ahli memvalidasi bahan ajar dari aspek kelayakan isi, kelayakan bahasa, dan kelayakan penyajian. Data keefektifan bahan ajar diperoleh dari hasil belajar mahasiswa pada pretest dan posttest uji coba lapangan. Data hasil validasi ahli dianalisis dengan menggunakan statistik deskriptif dan data hasil belajar mahasiswa dianalisis dengan menggunakan statistik inferensial uji t sampel berpasangan (paired sampel t-test). Indikator keberhasilan penelitian adalah: (1) bahan ajar dinyatakan layak jika total rata-rata hasil validasi ahli berada pada rentang $(3,5 \leq \mathrm{M} \leq 4)$ dan (2) bahan ajar dinyatakan efektif jika level signifikasi $<0,05$ berdasarkan hasil analisis statistik inferensial hasil belajar mahasiswa pretest dan posttest uji coba lapangan.

\section{HASIL DAN PEMBAHASAN}

\section{Hasil}

Paparan hasil penelitian ini dibagi menjadi dua bagian, yakni: (1) proses pengembangan bahan ajar dan (2) keefektifan bahan ajar. Uraian setiap bagian dipaparkan sebagai berikut.

\section{Proses dan Hasil Pengembangan Produk Bahan Ajar Menulis Opini dan Esai dengan Pembelajaran Berbasis Proyek}

Proses pengembangan bahan ajar pada tiap tahap pengembangan dideskripsikan sebagai berikut. Pertama, analisis subtansi bahan ajar menunjukkan bahwa dibutuhkan bahan ajar yang diorientasikan mengembangkan kemampuan mahasiswa agar terampil menyusun gagasan yang ditunjukkan melalui argumen, penalaran, dan data faktual pada tulisan opini dan esai. Dari analisis konteks, ditemukan bahwa fasilitas yang mendukung pengembangan bahan ajar berbasis proyek tersedia, yakni hotspot yang dapat digunakan untuk penelusuran literatur secara online dan perpustakaan Universitas Muhammadiyah Makassar yang dapat digunakan penelusuran literatur secara offline untuk penyusunan materi pembelajaran.

Kedua, desain. Kegiatan yang dilakukan pada tahap desain adalah merancang komponenkomponen bahan ajar. Hasil rancangan komponen bahan ajar, yakni (1) pengantar. Bagian pengantar memuat kerangka isi, tujuan, deskripsi singkat, dan relevansi isi bab materi pembelajaran. (2) Materi pembelajaran. Bagian materi pembelajaran memuat teori dan penjelasan pokok bahasan dan subpokok bahasan serta kegiatan yang dilakukan dengan pembelajaran berbasis proyek. (3) Rangkuman dan refleksi. Bagian rangkuman dan refleksi berisi ringkasan dan hubungan antar konsep atau prinsip yang dibahas pada materi pembelajaran. (4) Evaluasi. Bagian evaluasi memuat soal-soal dalam bentuk format soal uraian bebas yang juga diformat dalam bentuk tugas proyek.

Ketiga, pengembangan bahan ajar. Kegiatan yang dilakukan pada tahap pengembangan adalah penyusunan materi bahan ajar dan validasi ahli. Penusunan materi bahan ajar dilakukan dengan menulis bahan dari berbagai sumber yang relevan. Bahan ajar menulis opini dan esai berbasis proyek yang dikembangkan berupa buku setebal 108 halaman. Materi bahan ajar terdiri 6 Bab, yakni: (1) Bab I: Logika Tulisan Opini dan Esai, (2) Bab II: Argumen Tulisan Opini dan Esai, (3) Bab III: Penalaran Tulisan Opini dan Esai, (4) Bab IV: Topik Tulisan Opini dan Esai, (5) Bab V: Struktur Tulisan Opini dan Esai, dan (6) Bab VI: Metode Pengembangan Tulisan Opini dan Esai. 
Pada Bab I, aktivitas mahasiswa dilakukan untuk pembentukan kompetensi tentang hakikat dan jenis logika dalam tulisan opini dan esai. Proyek yang diselesaikan yakni menuliskan bentuk-bentuk logika yang digunakan dalam tulisan opini dan esai. Pada Bab II, aktivitas mahasiswa dilakukan untuk pembentukan kompetensi tentang hakikat dan jenis argumen dalam opini dan esai. Proyek yang diselesaikan, yakni menuliskan bentuk-bentuk argumen yang digunakan dalam tulisan opini dan esai. Pada Bab III, aktivitas mahasiswa dilakukan untuk pembentukan kompetensi tentang hakikat dan jenis penalaran dalam opini dan esai. Proyek yang diselesaikan, yakni menuliskan bentuk-bentuk penalaran yang digunakan dalam tulisan opini dan esai. Pada Bab IV, aktivitas mahasiswa dilakukan untuk pembentukan pemahaman tentang kriteria topik tulisan opini dan esai serta pengembangannya. Proyek yang diselesaikan, yakni menuliskan memilih dan mengembangkan topik tulisan opini dan esai. Pada Bab V, aktivitas mahasiswa dilakukan untuk pembentukan kompetensi tentang struktur tulisan opini dan esai serta pengembangannya, meliputi bagian pendahuluan, bagian inti/tubuh, bagian penutup. Proyek yang diselesaikan, yakni mengembangkan tulisan opini dan esai berdasarkan strukturnya. Bab VI, aktivitas mahasiswa dilakukan untuk pembentukan kompetensi tentang model-model pengembangan tulisan opini dan esai. Proyek yang diselesaikan, yakni mengembangkan tulisan opini dan esai berdasarkan model pengembangannya.

Pada setiap bab kegiatan dalam bahan ajar dilakukan melalui pembelajaran berbasis proyek yang mencakup 6 kegiatan, yakni (1) mengeksplorasi topik: mahasiswa melakukan eksplorasi secara untuk membentuk pemahaman awal tentang topik proyek yang akan diselesaikan; (2) brainstorming: mahasiswa mendiskusikan topik proyek masing-masing; (3) merencanakan proyek: mahasiswa menyusun rencana proyek yang mencakup sasaran yang hendak dicapai, bahan yang diperlukan, dan langkah-langkah yang akan dilakukan; (4) mengumpulkan informasi: mahasiswa mengerjakan proyek dengan memanfaatkan berbagai sumber daya yang tersedia, baik sumber offline maupun online. Produk yang dihasilkan dalam tahapan ini adalah draf awal tulisan; (5) presentasi proyek: mahasiswa menyajikan hasil penyelesaian proyek untuk memperoleh respon dan tanggapan. Setelah itu mereka melakukan revisi karya berdasarkan presentasi; dan (6) publikasi karya: memublikasikan tulisan sebagai produk akhir proyek yang dilakukan.

Keempat, validasi produk bahan ajar. Validasi ahli dilakukan oleh dua orang ahli. Validasi ahli dilakukan dengan menggunakan angket yang berisi kelayakan isi, kelayakan bahasa, dan kelayakan penyajian (adaptasi BSNP, 2006). Hasil penilaian validator I untuk kriteria kelayakan isi berdasarkan indikator cakupan materi $M=4$; akurasi materi $M=4$; kemutakhiran $M=3,5$; mengandung wawasan produktivitas $M=3,5$; merangsang keingintahuan (curiosity) $M=3,5$; mengembangkan kecakapan hidup (life skills) $M=4$; dan mengandung wawasan kontekstual adalah $M=3$.

Penilaian untuk kriteria kelayakan bahasa berdasarkan indikator sesuai dengan tingkat perkembangan peserta didik $M=4$; komunikatif $M=3,5$; dialogis dan interaktif $M=4$; lugas $M=3,5$; koherensi dan keruntutan alur berpikir $M=3,5$; kesesuaian dengan kaidah bahasa Indonesia $M=3,5$; dan penggunaan istilah $M=4$.

Penilaian kelayakan penyajian berdasarkan indikator teknik penyajian $M=4$, pendukung penyajian materi $M=4$ dan penyajian pembelajaran $M=4$. Nilai total rata-rata keseluruhan kriteria adalah $M=3,73$ berada pada kategori sangat layak.

Selanjutnya, penilaian validator II untuk kriteria kelayakan isi berdasarkan indikator cakupan materi $M=4$, akurasi materi $M=3$, kemutakhiran $M=3,5$, mengandung wawasan produktivitas $M=4$, merangsang keingintahuan ( $\mathrm{cu}$ riosity) $M=3,5$, mengembangkan kecakapan hidup (life skills) $M=4$ dan mengandung wawasan kontekstual adalah $M=4$. Penilaian untuk kriteria kelayakan bahasa berdasarkan indikator sesuai dengan tingkat perkembangan peserta didik $M=3$, komunikatif $M=4$, dialogis dan interaktif $M=3,5$, lugas $M=3,5$, koherensi dan keruntutan alur berpikir $M=3,5$, kesesuaian dengan kaidah bahasa Indonesia $M=4$ dan penggunaan istilah $M=4$. Penilaian untuk kriteria kelayakan penyajian berdasarkan indikator teknik penyajian $M=4$, pendukung penyajian materi $M=3,5$ dan penyajian pembelajaran $M=3$. Nilai total rata-rata keseluruhan kriteria adalah $M=3,67$ berada pada kategori sangat layak

Berdasarkan hal tersebut di atas, bahan ajar menulis opini dan esai berbasis proyek dinyatakan layak berdasarkan hasil validasi ahli karena kriteria layak telah terpenuhi. Hal tersebut, sejalan dengan yang dikemukakan Nurdin (2007) bahwa bahan ajar menulis opini dan esai berbasis 
Tabel 1. Hasil Uji Normalitas Hasil Belajar Mahasiswa

\begin{tabular}{ccccccc}
\hline & \multicolumn{2}{c}{ Kolmogorov-Smirnov(a) } & \multicolumn{3}{c}{ Shapiro-Wilk } \\
\cline { 2 - 7 } & Statistic & Df & Sig. & Statistic & df & Sig. \\
\hline Pretest & .105 & 35 & $.200\left(^{*}\right)$ & .948 & 35 & .100 \\
\hline Postest & .103 & 35 & $.200\left(^{*}\right)$ & .979 & 35 & .736 \\
\hline
\end{tabular}

Tabel 2. Hasil Uji Homogenitas Hasil Belajar Mahasiswa

\begin{tabular}{cccc}
\hline Levene Statistic & df1 & df2 & Sig. \\
\hline 11.120 & 1 & 68 & .001 \\
\hline
\end{tabular}

Tabel 3. Hasil Uji t-test Hasil Belajar Mahasis wa

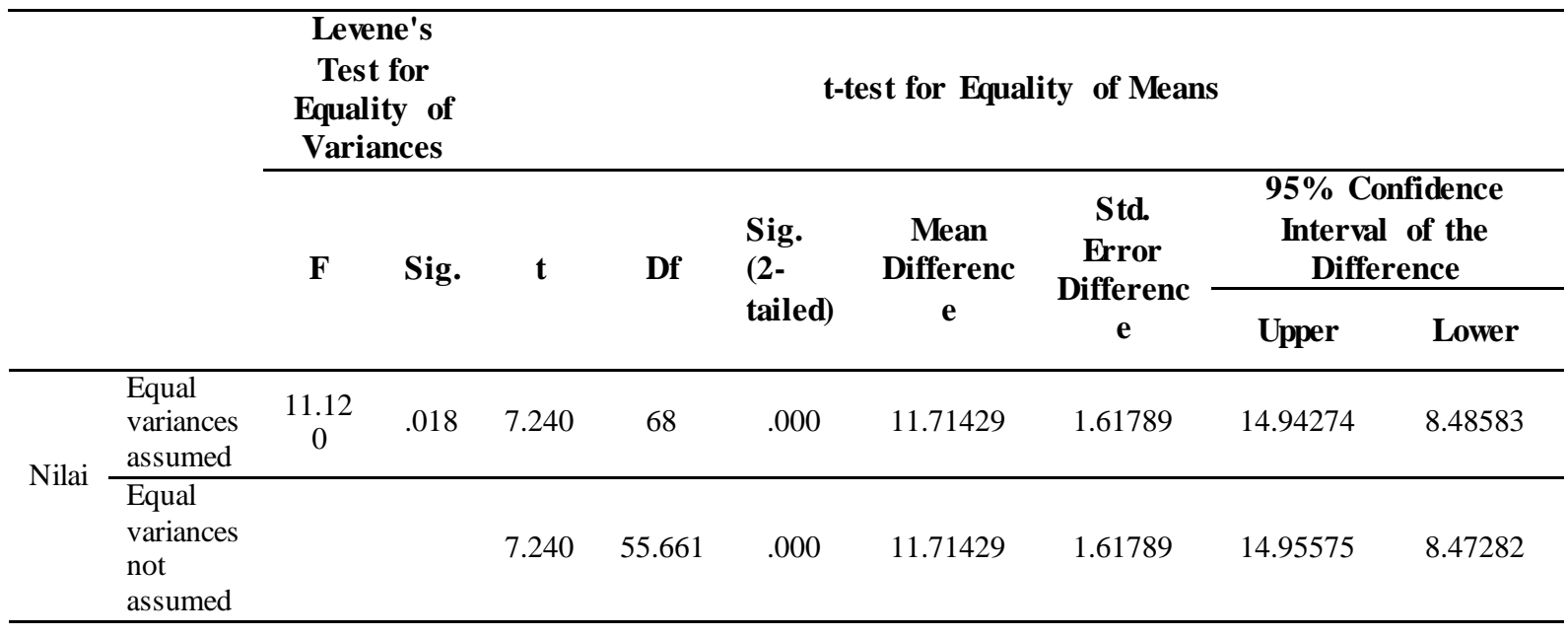

proyek dinyatakan layak apabila nilai total ratarata kelayakan hasil validasi ahli berada pada rentang $(2,5 \leq \mathrm{M}<3,5)$.

Keefektifan Bahan Ajar Menulis Opini dan Esai dengan Pembelajaran Berbasis Proyek

Data keefektifan bahan ajar menulis opini dan esai berbasis proyek diperoleh dari hasil belajar mahasiswa pretest dan posttest. Berdasarkan hasil uji coba, diperoleh rata-rata skor pretest mahasiswa sebesar 74,51, sedangkan rata-rata skor postest 86,23. Berdasarkan hasil analisis deskriptif diketahui peningkatan rata-rata hasil belajar mahasiswa sebesar 11,71.

Sebelum data uji coba lapangan dianalisis dengan statistik inferensial terlebih dahulu diuji normalitas dan homogenitasnya. Uji normalitas hasil belajar mahasiswa dilakukan dengan uji statistic lilliefors (Kolmogorov-Smirnov. Berdasarkan, hasil analisis diketahui bahwa hasil uji normalitas menunjukkan hasil belajar mahasiswa pada pretest dan postest berasal dari populasi yang berdistribusi normal karena nilai $p=0,105$ dengan signifikansi $=0,200$ untuk pretest dan $p=0,103$ dengan signifikansi 0,200 untuk posttest . Hasil lengkap uji normalitas data disajikan pada Tabel 1.

Uji homogenitas hasil belajar mahasiswa pada pretest dan posttest dilakukan dengan uji statistic test of homogeneity of variances dengan ketentuan jika signifikansi p>0,05, maka data dinyatakan homogen. Sebaliknya, jika signifikansi $\mathrm{p}<0,05$ maka hasil belajar dinyatakan tidak homogen. Hasil uji homogenitas hasil belajar mahasiswa pada pretest dan posttest dinyatakan homogen karena nilai $p=11,120$ dengan signifikansi 0,01. Hal ini menunjukkan bahwa $p>0,05$. Hasil lengkap uji homogenitas data disajikan pada Tabel 2.

Setelah dilakukan uji prasyarat,selanjutnya dilakukan uji-t untuk menguji hipotesis. Uji-t data hasil belajar mahasiswa pada pretest dan posttest dilakukan dengan uji paired samples t-test dengan ketentuan jika nilai $\mathrm{p}>0,05$, maka hipotesis dinyatakan diterima. Sebaliknya, $\mathrm{p}<0,05$, 
maka hipotesis dinyatakan ditolak. Berdasarkan hasil uji t-test diperoleh bahwa nila $\mathrm{p}=0,000$. Hasil lengkap hasil uji-t keefektifan ba-han ajar menulis opini dan esai dengan pem-belajaran berbasis masalah disajikan pada Tabel 3 . Berdasarkan hasil tersebut, ditemukan bahwa ada perbedaan signifikan antara nilai pretest dan postest menulis opini dan esai mahasiswa. Dengan demikian, bahan ajar menulis teks opini dan esai dengan pembelajaran berbasis proyek disimpulkan efektif untuk meningkatkan hasil belajar mahasiswa.

\section{Pembahasan}

Pembahasan hasil penelitian ini dipilah menjadi dua bagian, yakni pemaknaan hasil pengembangan produk dan pemaknaan terhadap hasil uji keefektifan produk. Pertama, pemaknaan hasil pengembangan produk. Melalui rangkaian kegiatan penelitian dan pengembangan telah dihasilkan produk menulis opini dan esai dengan pembelajaran berbasis proyek. Karakteristik pertama yang menjadi penciri dan sekaligus pembeda produk penelitian ini dengan produk penelitian lainnya adalah pada struktur dan subtansi bahan ajar yang dikembangkan. Melalui bahan ajar yang dikembangkan ini, mahasiswa dituntun untuk mengembangkan kompetensi menulis opini dan esai dengan memperhatikan logika, argumen, dan penalaran. Pemanfaatan elemenelemen tersebut dalam menulis diperlukan untuk menghasilkan tulisan opini dan esai yang terstruktur dan mampu meyakinkan pembaca. Pada hakikatnya, menulis opini dan esai adalah menulis untuk meyakinkan. Dalam konteks ini, elemen logika, argumen, dan penalaran yang baik diperlukan untuk menjadikan tulisan yang dihasilkan memiliki daya pengaruh bagi pembaca. Setiawati dan Nurlaelah (2017) dalam penelitiannya menemukan bahwa hanya enam persen guru dan mahasiswa calon guru yang mampu mencapai level 4 (level tertinggi) dalam memberikan argumentasi, yakni argumentasi yang disertai dengan klaim, bukti, dan sanggahan. Produk yang dihasilkan dalam penelitian ini dapat menjadi alternatif pengembangan kompetensi berargumentasi mahasiswa melalui kegiatan menulis opini dan esai.

Karakteristik kedua bahan ajar yang dikembangkan dengan pendekatan berbasis proyek ini adalah memberikan kesempatan kepada mahasiswa untuk terlibat aktif dalam setiap tahapan kegiatan. Pada setiap unit kegiatan belajar mahasiswa melakukan kegiatan yang terdiri atas enam tahap, yakni (1) mengeksplorasi topik, (2) brainstorming, (3) merencanakan proyek, (4) mengupulkan informasi, (5) presentasi proyek, dan (6) publikasi karya. Rangkaian kegiatan ini menuntut mahasiswa untuk terlibat secara intensif pada setiap rangkaian kegiatan belajar. Rangkaian kegiatan yang didesain tersebut membantu mahasiswa mendalami topik, merencanakan, mengembangkan, dan menyajikan hasilnya. Mahasiswa memiliki kesempatan belajar secara bermakna.

Keunggulan bahan ajar menulis opini dan esai berbasis proyek adalah menuntun mahasiswa untuk menggali konten (substansi materi) dengan menggunakan berbagai cara yang bermakna bagi dirinya dan melakukan eksperimen secara kolaboratif untuk menghasilkan tugas proyek berupa tulisan opini dan esai. Dengan demikian, mahasiswa dituntut untuk merancang suatu proyek dengan mengikuti langkah-langkah kegiatan yang menerapkan model pembelajaran berbasis proyek secara konsisten dan sistematis.

Karakteristik ketiga bahan ajar menulis opini dan esai ini adalah dikembangkan sesuai dengan gaya belajar mahasiswa saat ini. Dalam rangkaian kegiatan penyelesaian proyek, mahasiswa memiliki keleluasaan untuk memanfaatkan beragam sumber dari internet. Durasi waktu penyelesaian proyek yang panjang memungkinkan mahasiswa mengeksplorasi berbagai sumber untuk dijadikan bahan tulisan. Sebagaima diketahui bahwa saat ini internet telah menjadi sumber utama dalam pencarian referensi dan pemanfaatan sumber belajar. Soenhadji \& Susiloatmadja (2007) melaporkan bahwa mahasiswa yang mengakses internet untuk penyelesaian tugas akhir memiliki keyakinan menghasilkan tugas lebih baik dibandingkan mereka yang tidak mengakses internet untuk penyelesaian tugas. Temuan yang sama didapatkan oleh Kaliky (2013) yang mengungkap bahwa pemanfaatan internet oleh mahasiswa telah membantu memenuhi kebutuhan pembelajaran, khususnya dalam penyelesaian tugas-tugas.

Bahan ajar yang dihasilkan telah memenuhi kriteria kevalidan bahan ajar. Aspek-aspek yang dinilai oleh validator telah memenuhi kriteria minimal, yakni kategori baik. Menurut BSNP (2006), bahan ajar yang berkualitas wajib memenuhi aspek kelayakan, meliputi kelayakan isi, kelayakan penyajian, kelayakan bahasa, dan kela- 
yakan kegrafikaan. Berdasarkan hasil pengolahan data, bahan ajar menulis opini dan esai berbasis proyek telah memenuhi kriteria kelayakan. Hal ini mengindikasikan bahwa bahan ajar memenuhi kualitas dan dapat digunakan secara luas.

Kedua, pemaknaan hasil uji keefektifan. Melalui uji keefektifan ditemukan bahwa bahan ajar efektif untuk meningkatkan keterampilan mahasiswa menulis opini dan esai. Hasil belajar yang diperoleh tersebut disimpulkan sebagai dampak dari pembelajaran berbasis proyek. Melalui bahan ajar menulis opini dan esai dengan pembelajaran berbasis proyek mahasiswa dapat mengkreasikan ide secara leluasa dan berinteraksi dengan sumber belajar dan sesama mahasiswa. Sintaks bahan ajar mendorong mahasiwa untuk berkesprimen dengan ide dan gaya menulis yang baru. Pirsl, Pirsl, dan Kesic (2011) mengungkapkan bahwa penulis yang memiliki kebebasan mengekspresikan diri memiliki kecenderungan menikmati ide-idenya dan menyalurkannya menjadi tulisan yang baik.

Salah satu aspek pembelajaran yang menonjol dalam bahan ajar menulis opini dan esai dengan pembelajaran berbasis proyek adalah keterlibatan aktif mahasiswa pada setiap kegiatan belajar. Menulis merupakan kegiatan yang membutuhkan pelatihan dan pengulangan. Kesempatan berlatih yang berulang-ulang ini juga memberi kontribusi terhadap pembentukan kompetensi menulis mahasiswa. Hal ini sesuai dengan pendapat Afrin (2016) yang mengemukakan bah-wa proses belajar menulis akan maksimal jika (1) mahasiswa bertindak sebagai pusat aktivitas, (2) tugas dan pelatihan dilakukan secara intensif, dan (3) mahasiswa memperoleh tantangan dalam tugas menulis.

Keberhasilan bahan ajar meningkatkan hasil belajar mahasiswa tidak lepas dari karakteristik pembelajaran berbasis proyek yang mampu memotivasi mahasiswa. Motivasi mahasiswa muncul salah satunya bersumber dari kegiatan belajar yang berbeda dan keluar dari rutinitas belajar yang umumnya dilakukan di dalam kelas. Motivasi mahasiswa tergambar dari antusiasme

\section{DAFTAR PUSTAKA}

Afrin, S. 2016. Writing Problem of Non-English Major Undergraduate Students in Bangladesh: An Observation. Open Journal of Social Science, 4: $104-115$. dan semangat menyelesaikan proyek menulisnya. Hal ini sejalan dengan temuan Prabawa (2013) yang menemukan bahwa unsur proyek otentik memiliki peran menggugah motivasi belajar dan menciptakan proses belajar yang bermakna.

Selain keunggulan yang dimiliki, bahan ajar menulis opini dan esai dengan pembelajaran berbasis proyek ini juga memiliki kelemahan. Pembelajaran berbasis proyek memerlukan durasi waktu yang lama untuk melakukan aktivitas dari perencanaan hingga penyelesaian proyek. Dengan jadwal kuliah yang padat, hal ini akan menyulitkan mahasiswa.

\section{SIMPULAN}

Berdasarkan hasil penelitian dan pembahasan hasil penelitian dapat disimpulkan bahwa bahan ajar menulis artikel opini dan artikel esai berbasis proyek yang dikembangkan telah layak dan efektif digunakan dalam pembelajaran menulis opini dan esai pada program Studi Pendidikan Bahasa dan Sastra Indonesia, Universitas Muhammadiyah Makassar. Bahan ajar layak digunakan karena telah memenuhi aspek kelayakan, yakni kelayakan isi, kelayakan penyajian, dan kelayakan bahasa. Bahan ajar efektif digunakan karena terdapat perbedaan yang siginifikan hasil belajar mahasiswa sebelum mengunakan dan setelah menggunakan bahan ajar. Berdasarkan hasil tersebut, dosen direkomendasikan menggunakan bahan ajar ini dalam menulis opini dan esai di perguruan tinggi.

\section{UCAPAN TERIMA KASIH}

Penulis menyampaikan ucapan terima kasih kepada mitra bestari (reviewers) yang telah memberikan saran, kritik, dan rekomendasi perbaikan artikel ini. Ucapan terima kasih juga disampaikan kepada validator, dosen, dan mahasiswa yang telah berpartisipasi dalam pelaksanaan uji coba produk bahan ajar.

BSNP. 2006. Instrumen Penilaian Tahap I Buku Teks Pelajaran. Jakarta: BSNP.

Dimyati dan Mudjiono. 2013. Belajar dan Pembelajaran. Jakarta: PT Rineka Cipta. 
Finoza, L. 2009. Komposisi Bahasa Indonesia. Jakarta: Insan Mulia.

Gasman, M. 2014. How to Write an Opinion Essay and Why You Should Do It Now. Phi Delta Kappan, 96 (1): 28-29, doi: doi.org/10.1177/ 0031721714547858

Kaliky, P. I. 2013. Pemanfaatan Internet dalam Pembelajaran Mahasiswa di Universitas Pattimura, Ambon. Jurnal Komunikasi Kareba, 2 (1): 110-120.

Kellog, R. T. and B. A. Raulers on III. 2007. Improving the writing skills of college students Psychonomic. Bulletin \& Review, 14 (2): 237-242.

Nurdin. 2007. Model Pembelajaran yang Menumbuhkan Kemampuan Metakognitif untuk Menguasai Bahan Ajar. Disertasi. Surabaya: Program Pascasarjana Universitas Negeri Surabaya.

Mulyatiningsih, E. 2012. Metode Penelitian Terapan Bidang Pendidikan. Bandung: Alfabeta.

Persadha, D. A. K. 2016. Studi Kompetensi Kemampuan Menulis di Kalangan Mahasiswa. MUADDIB, 6 (1): 1-20.

Perutz, V. 2010. A Helpful Guide to Essay Writing! Cambridge and Chelmsford: Anglia Ruskin University.

Piršl, D., T. Piršl, \& D. Kesić. 2011. Writing Skills at University Level. Sport Logia, 7 (1): 69-72, doi: 10.5550/s gia.110701.en.069P

Rasyidah, U. \& R. Antoni. 2014. Analisis Kemampuan Mahasiswa Pendidikan Bahasa Inggris Semester VI Universitas Pasir Pengairan dalam Menulis Critical Essay. Jurnal Ilmiah Edu Research, 3 (1): 21-30.
Sakaria, Anshari, \& Nurhikmah. 2016. Teaching Material Development of e-Learning-Based Argumentation Discourse Writing with ProjectBased Learning Model. Journal of Language and Literature, 7 (4): 154-169, doi: dx.doi.org/ 10.7813/j11.2016/7-4/2

Sanjaya, W. 2010. Strategi Pembelajaran Berorientasi Standar Proses. Jakarta: Prenada Media Group.

Setiawati, I. \& I. Nurlalelah. 2017. Analisis Profil Kemampuan Berargumentasi Guru dan Mahasiswa Calon Guru dalam Pembelajaran Biologi Menggunakan Model Toulmin's Argumen Pattern (TAP) dan Upaya Perbaikannya. Quagga, 9 (1): 1-16.

Soenhadji, I. M. \& R. Susiloatmadja. 2007. Pemanfaatan Internet oleh Mahasis wa sebagai Media Pencarian dan Penelusuran Informasi. Jurnal Ekonomi Bisnis, 3 (12): 189-198.

Suhartatik \& Adi. 2014. Pengembangan Model Project-Based Learning untuk Meningkatkan Kemampuan Bahasa Inggris Siswa Ponpes Modern di Malang Raya. Lingua, 9 (2): 1-7.

Tamim, S. R. \& M. M. Grant. 2013. Definitions and Uses: Case Study of Teachers Implementing Project-based Learning. Interdisciplinary Journal of Problem-Based Learning, 7 (2): 71-101, doi: 10.7771/1541-5015.1323

Trianto. 2012. Model Pembelajaran Terpadu.Jakarta: Bumi Aksara.

Wajdi, F. 2017. Implementasi Project Based Learning (PBL) dan Penilaian Autentik dalam Pembelajaran Drama Indonesia. Jurnal Pendidikan Bahasa dan Sastra, 17 (1): 81-97. 